\title{
The Activity of Speaking
}

\section{Jesus Martinez del Castillo}

Department of Philology, Faculty of Business Studies and Tourism, Universidad de Almería, Almería, Spain

\section{Email address:}

jesus.gerardo@ual.es, apofansis@msn.com

\section{To cite this article:}

Jesús Martínez del Castillo. The Activity of Speaking. International Journal of Language and Linguistics. Special Issue: Linguistics of Saying. Vol. 3, No. 6-1, 2015, pp. 59-66. doi: 10.11648/j.ijll.s.2015030601.18

\begin{abstract}
The most comprehensive manifestation of language can be seen in the activity of speaking. In itself the activity of speaking cannot be understood unless it is referred to the concepts of language and a language. Anything in language can be found in the activity of speaking. Because of this you can find what language is if you abstract from the innumerable manifestations of the activity of speaking.
\end{abstract}

Keywords: The Act of Knowing, the Human Free and Creative Cognizant Subject, the Degree of Reality of Speaking, Knots of Connections, a Theory of Knowledge, the Radical Reality

\section{The Degree of Reality of Speaking: Aspects in It $^{1}$}

The activity of speaking does not constitute a simple reality but a complex one. It involves other activities, some of them directly observable, and some manifesting themselves if we add something to the facts observed. On the other hand, the activity of speaking is not given in itself: it manifests itself in other activities perfectly liable to be observed and analysed in themselves. In the activity of speaking we can see the following aspects or activities:

1. The systematic utterance of sounds combined with one another. This activity has concrete existence since it is observable and reproducible. Speaking manifests itself in something concrete such as linguistic sounds. But this activity involves two aspects: it has an aspect perfectly observable since it is concrete, and another one liable to be observed only if we add something on our part to understand the combination it appears in. We can say, for example, that in a particular language this sound may constitute a phoneme and this one may not, that is, the former has functional relevance but not the latter. That is, we must interpret sounds with something invented or fabricated on our part: it is necessary to examine them in

\footnotetext{
${ }^{1}$ This article continues with the problem posed in article [6], Jesus Martinez de Castillo, Determining the Degree of Reality of Language, International Journal of Language and Linguistics. Special Issue:Linguistics of Saying. Vol. 3, No. 6-1, 2015, pp. 39-49.
}

terms of a particular idea. With this we have created the concept (the phoneme) that some sounds have relevance and some sounds are mere variations of those with relevance. Eventually we shall say that all sounds in a particular language will function, but considering them as belonging to certain classes we have previously defined. These classes (phonemes) constitute something added by us, that is, they constitute the interpretation (theory) we add to facts. With this creation we can systematise all sounds and establish the rules governing them. Once they have been systematised, we can say how they are to be combined, what is their significance, and establish the rules to combine sounds, and how they function.

The first conclusion we can draw from this initial observation is that sounds do not represent anything able to exist in what they appear to be. Sounds are given in terms of something else, just what we are looking for, language. Sounds have concrete existence but their existence evokes something non-concrete, something going beyond sounds: the motivation of their production and combination and thus the function they play. Sounds cannot be identified with either the activity of speaking, language, or the historical language, the realities we are just examining in order to look for the reality of what we call language is based on.

The activity of speaking manifests itself as well in,

2. Designation, that is, the relationship established between the linguistic expression and things in the world. Human subjects wherever they are will establish some connection with the things surrounding them. This fact 
involves the following one.

3. The establishment of an order on the world surrounding us, thus making it into things and a world consisting of things.

4. This order established on the world surrounding us, constitutes a linguistic world referring to the reality surrounding us. This reality surrounding us, changes depending on the particular language being spoken.

5. Both designation and the establishment of a linguistic world involve, as something previous to them, what we call knowledge or the act of knowing by the speaking subject, that is to say, the act of apprehending the things constituting the circumstance the cognizant subject is $\mathrm{in}^{2}$, feeling conscious of the things apprehended.

6. In our apprehension of things, we do not apprehend things mechanically. We apprehend only some aspects in a chaotic way, always guided by our interest. In this way our apprehension of things is unpredictable. In this we meet something we did not anticipate at the beginning of our foray, freedom. Human subjects are free to know. We apprehend something only if we realize it and voluntarily fix our attention on it, that is, if we are interested in recognizing the thing coming to us through our senses. Every individual subject in every situation he is, will realize of some particular aspects because he pays attention to them. Never two subjects will apprehend the same aspect of something nor will they apprehend the same thing in the same way.

7. The fact human knowledge is based on. In this fact we can distinguish two aspects: what we apprehend through our senses and what we voluntarily select from the thing given by our senses. That is, we have two different realities: what comes up to us through our senses, something concrete and sensitive, putting us into contact with the things surrounding us, intuition, or aisthesis as Aristotle would $\mathrm{say}^{3}$, and what we voluntarily select from aisthesis, thus making it something completely different from the concrete and sensitive, that is, something non-concrete and non-sensitive, that is, mental, abstract, something we have created or fabricated.

8. The conclusion we can draw from this fact is that in knowledge the synthesis said by Kant is given between two different and opposite things, incompatible with each other: the sensitive and the abstract, concrete and mental, or sensibility and intellect, or said in other words: sensitive and concrete is made into mental and abstract ${ }^{4}$.

9. In this way, within human knowledge, we have to distinguish two different realities,

a. The reality of knowledge. We know something by inventing something out of something existing, and

b. The reality of the object known. That thing once selected and made into abstract is attributed reality, given limits,

\footnotetext{
2 Ortega y Gasset 1994, p. 190.

${ }^{3}$ De Anima III, 1, 425a, 14 apud Ortega y Gasset 1992a, p. 128.

${ }^{4}$ Cf. Kant 2004, p. 47-52; Di Cesare 1999, pp. 35-36.
}

given an essence to be, given a name and orientated to reality.

10. But in this fact in which we have apprehended something and made into abstract from the thing given to us through our senses, freedom is present. The reality of freedom thus is given in knowledge but goes beyond knowledge. We know only those things we realize, that is, we know only those things we pay attention to. And in this we can see that beyond freedom there is a subject who is able to realize, pay attention to and be interested in things outside him, thus selecting something from the thing given by his senses. In a word: beyond human senses and human knowledge the human subject is.

11. This fact makes us conclude about the procedure initiated, and analyse its implications. Our problem now is to determine if the thing known - whenever we know, language is implicit-has reality in itself or is something merely fabricated by us. We as cognizant subjects know, but the thing known by us as cognizant subjects is filtered with freedom, on the one hand, and with language, on the other. What eventually the subject knows is nothing but a linguistic world, in which he lives and tries to survive. We create what we know, and filter it through language, thus believing that our world is real, the world we speak of and in accordance with we think. But we cannot know any other world. That is, we created a linguistic world, developed ourselves in that linguistic world and survived in that linguistic world.

12. The establishment of a linguistic world involves, since the only one who knows and speaks is the individual subject, establishing something else (a motivation and an object or part of an object) to define ourselves as individuals in a particular moment and particular setting or circumstance. This defining ourselves involves three things:

a. First, the execution of the act of knowing, aimed at achieving something. The definition of ourselves is $a$ free action. Knowledge, on the other hand, is end-oriented, that is, it is made in terms of something else.

b. Second, the simultaneous creation of particular states of affairs. The cognizant subject himself executes his own being in the world with a pragmatic vision of the things surrounding him. The linguistic world thus is arbitrary, that is, end-oriented and motivated only historically ${ }^{5}$.

c. Third, since the creation of words is end-oriented, the speaking, saying and cognizant subject constitutes himself in the guarantee of the state of affairs stated, that is, compromises before things and his co-speakers ${ }^{6}$.

13. Defining ourselves before the things known, that is, before what we have created and fabricated, means that the things before us, created by us, must necessarily be something mental consisting in the establishment of $a$

\footnotetext{
${ }^{5}$ Cf. Coseriu 1988, p. 24, footnote 38; Coseriu 1985a, pp. 37-38

${ }^{6}$ Cf. Martínez del Castillo 2004.
} 
set of connections on a particular aspect constituting the linguistic world in which we move and live. This activity aimed at a particular purpose we develop our freedom on, can be decomposed in two realities:

- The activity in itself, saying, and

- The object on which that activity is performed, the object of saying.

14. But this is not either what we were looking for. Neither the object of saying or saying itself, because of their individual, momentary and sporadic nature, constitutes anything able to be verified. However they constitute something able to be observed if we add something on them. We can make synthetic a priori statements ${ }^{7}$ on them, and then deduce from these statements. But with this procedure we cannot say that they constitute anything reliable to base a theory on. Both saying and the object of saying, out of the many things constituting the reality of language, are the most unreliable. They both evince the individual freedom of the speaking subject to know and the determination of knowing, saying something.

15. The creation of a state of affairs or many states of affairs with application only in the moment of speaking constitutes what we call a sense, a particular circumstantial aspect of the linguistic order established. The acceptance of the many senses given in the activity of speaking within a speech community as something common may constitute what we by abstraction call meaning, an ideal reality functioning as virtual in a speech community, consisting in the systematization of facts of experience ${ }^{8}$.

16. The activity of speaking manifests itself as well as mental activity, that is, as the cognizant activity ${ }^{9}$ implicit in all manifestations of speaking. Mental activity does not manifest itself directly but always in something else. Mental activity manifests itself especially in the act of knowing or the act of transforming what comes up through our senses, something sensitive and concrete, into something apt to be manipulated, something abstract. Once that mental and abstract thing is made into words with designation in the linguistic world we live in, and once it is said to another cognizant subject, we find out language and a particular language.

17. On the other hand, speaking is speaking and understanding. We speak and say something because we have an idea about reality or understand something about it. Understanding involves two things:

- On the one hand, he who speaks understands or thinks he understands something; as a consequence, he knows reality and interprets reality;

- On the other hand, he who speaks is not alone. We speak, that is, utter sounds for speaking and saying something because we want to make somebody else understand. In this sense, we shall always suppose two participants, the speaker and the listener, both interchanging the roles of speaker and listener, thus constituting $\delta \alpha_{\alpha} \lambda \mathrm{o} \gamma \mathrm{o} \varsigma^{10}$ and executing the speech act.

18. Speaking or the activity of speaking is the most genuine manifestation of language, the one putting together the realities already analysed of language and the particular language, including in it the four realities analysed so far: language as something absolute and universal, language as something virtual, language as activity, and language as mental activity; that is and said in other words: the realities of language as something absolute and contingent and the manifestations of themselves: speaking and understanding, realities we must always bear in mind.

19. Speaking as an activity involves:

I. A subject who is able to perform that kind of activity, that is, a subject, able to know, apprehend being, systematize what he apprehends, determine it thus orienting it to real things and express it in words; a subject who is at the same time able to understand the order imposed on the world, that is, a subject who must necessarily be free and creative and thus intelligent. At the same time, the free subject must be contingent and limited, since he must necessarily express his ideas, execute his act of knowing and understand the things surrounding him in material words and expressions, not belonging to him but the community.

II. The thing made, the manifestation of the intelligence, freedom and historicity of subjects executing the activity of speaking. The thing made, in principle, is something abstract, that is, something needing interpretation.

III. The technique used to execute the activity, that is, the knowledge, creative and contingent, used for the execution of the activity of speaking.

20. Speaking as an activity in its contents, as we have just said, relates to a subject performing the activity. Speaking is, at the same time, speaking and understanding and both the speaker and the listener constitute the speech act. The activity of speaking from the point of view of the speech act is nothing but the activity executed by the speaker in order to let the listener understand. In this sense speaking is speaking to others. That is, speaking is the relationship of participation of the speaker with the listener, both constituting the speech act. Because of speaking and participating in a speech act, both the speaker and the listener manifest themselves to each other using something in common. The speaker speaks to the listener and the listener takes his turn to speak to the first speaker. Because of this they will go out of themselves in accordance with the conventions of a particular moment in history, that is, they will manifest

\footnotetext{
${ }^{7}$ Cf. Kant 2004, p. 47-52. Cf. as well Ortega y Gasset 1989, pp. 13-14.

${ }^{8}$ Cf. Coseriu 1981, p. 88.

${ }^{9}$ Coseriu 1985a, p. 42.
} 
at each other with something in common. The thing they have in common constitutes what we call the particular language. Human subjects thus are historical. They manifest themselves to one another because they participate in the same level of historicity. Languages at the same time are historical, that is, made in history in a particular speech community, thus constituting the means and the manifestation of human historicity to others.

21. With this, language, the activity of speaking manifests itself in a quadruple dimension:

1) First, language evincing the subject, the "I", as someone performing his freedom and intelligence.

2) Second, language evincing the definition of the free, creative, absolute and intelligent subject before the world surrounding him.

3) Third, language evincing the activity performed by this free, creative, absolute and intelligent subject involving others and creating the means of expression good for him and the others.

4) And fourth, language revealing the subject involving and adapting to others: in this sense the subject creates the means of expression at the same time common and participated, made in history and thus contingent and limited. These dimensions could be summarized in the following way:

i The subject as he performs his freedom and intelligence.

ii The subject as he acts in his circumstance.

iii The subject as he aims at others thus creating means of expression.

iv And the subject as he has something in common with the others.

For Coseriu, language has two dimensions, the dimension subject-object, objective dimension, and the dimension subject-subject, subjective dimension ${ }^{11}$. Because of the first dimension language has to do with the relationship of the speaking subject with things in the world. That is, language has to do with the creation of things and concepts making up things in the world. For Coseriu, language does not create things but delimits species, that is, language presents things as existing as members of a particular category ${ }^{12}$. Because of the second dimension, language has to do with the speaking subject and the others. That is, language is aimed at others, language is for others, the speaking subject presupposes the existence of the other, at least with the same capacity to speak as he himself has.

Since language is nothing existing but the reaction of the subject before the circumstance he is involved in and since

\footnotetext{
${ }^{11}$ Coseriu says: " Man lives in a linguistic world created by him as a historical being. These are the two essential dimensions of language: the dimension subject-object and the dimension subject-subject. As language in general, language belongs to the first dimension, to the connection of Man with being. Language as a language at the same time relates to the connection of Man with the other Men, whom just because of language he attributes 'humanity', the ability to ask for being and interpret it" (Coseriu 1985a, pp. 32-33, my translation).

${ }^{12}$ Cf. Coseriu 2006, pp. 73-74.
}

language must be described in its birth, both dimensions by Coseriu must be divided in the way said above. For Coseriu, both dimensions of language answer to language as it appears in itself. For me, the division of the dimensions by Coseriu, answers to the reality of the speaking subject who is in a particular circumstance ${ }^{13}$. From this point of view language appears in its birth.

But let us continue with our analysis and end it up.

22. The common or participated dimension of language manifests itself in the participation of speakers when speaking; that is to say, it manifests itself in the particular language or the speech community. In this sense language manifests as participated, that is, as $a$ particular or historical language. Language is created by all speakers in a speech community, a community of free speakers made in history.

\section{What We Can Verify and What We Add}

Summing up, we can verify the existence of speaking and thus the degree of reality of it but only fragmentarily. We shall always find out a minimum part of it. The reality manifesting itself is the thing being made by free, absolute, and contingent subjects. But the thing being made, however perfect it may be, will never reveal the thing underlying it unless through reflexion and interpretation. The thing underlying speaking and all aspects involved in it, is human subjects, an agent always present and supposed to be present in speaking. With this, we can guess the potentiality of language by means of a series of syntheses of the human subject and the circumstance he is involved in. Given the heterogeneity of the thing performed, in the concept of speaking it is much more what we add (by means of deduction, analogy or creation) than the thing actually verified. The things constituting the circumstance of the individual speaker are always present in speech, although not mentioned. This lets Ortega y Gasset say:

[...] language consists not only in saying what by means of it is said, but in performing that executing meaningful saying capacity of contour. It is really surprising how words integrate as words [...] suddenly coalescing with the nearby things and entities, which are non-verbal. What words mean is very little, but constitute the percussion tool shooting the quasi-verbal power of anything surrounding the subject ${ }^{14}$.

The reality of speaking is given in all speakers, everywhere and every when, in all types and ways of speaking. But it is always new. In itself speaking is unapproachable. Speaking is a concept including what we can verify directly and many things we can verify but introducing in it something we create, that is, something we add to achieve our verification. In this

\footnotetext{
13 Ortega y Gasset defines a human being in the following way: "acting coexistence of me or I with the circumstance or the world. [...] I call this coexisting "my life". [...] It is me who exists [...] but this existing and, thus, I, consists in coexisting with "the other", with [the things in] the world" (1992b, pp. 41-46).

${ }^{14}$ Ortega y Gasset 2001, p. 241 (my translation).
} 
sense the description of speaking cannot be but interpretation, that is, hermeneutics. The problem in the study of speaking is what we add to its concept in order to understand it. This makes us conclude that the theory we create must be adequate to this manifold reality.

\section{The Role of the Speaking Subject}

But the activity of speaking, from the point of view of the subject performing it, can constitute the real basis in order to establish a theory. In the speaking subject we can base a theory about language and all aspects included in it. The subject executing the activity of speaking is, in accordance with the analysis made so far, a subject who

I. Utters sounds, that is, who speaks;

II. Designates some aspects in the world surrounding him thus creating things;

III. Creates a linguistic world in which he performs himself as a member of a speech community;

IV. Knows, that is,

V.Apprehends the things surrounding him by means of his sensibility through his senses;

VI. Transforms the thing apprehended in a sensitive way into something abstract by means of his mental activity;

VII. Designates things surrounding him with the forms he has just abstracted from the sensitive thus adding something to interpret things;

VIII. Creates his object of knowing;

IX. Manifests himself and executes his freedom when he knows;

X.Creates states of affairs liable to be designated thus creating meanings and senses;

XI. Defines himself before the things surrounding him, apprehending and transforming them, thus creating a saying;

XII. Understands thus creating ideas about things and the world;

XIII. Manifests himself to another subject;

XIV. Creates his conscience participating with others;

$\mathrm{XV}$. Creates an objet of saying (his meaningful intentional purpose) and a sense;

XVI. Uses common means of expression (ways of expression such as meanings) to manifest himself to others thus contributing to create a particular language thus constituting a linguistic community;

XVII. Performs all this as a cognizant subject executing an activity proper of his own, the activity of a subject "thrown" to be in this world where he must make himself in struggle against the circumstance ${ }^{15}$.

\section{The Radical Reality}

The concept of speaking or activity of speaking manifests

\footnotetext{
${ }^{15}$ Cf. Ortega y Gasset 1999, p. 119; Ortega y Gasset 2005, 135; etc.
}

itself in the many aspects analysed, based on the subject who speaks, apprehends the things surrounding him, transforms what comes to him through his senses, creates the linguistic world he lives in thus creating reality, re-structures the things surrounding him thus saying something and constituting himself in the guarantee of it. The cognizant, saying and speaking subject, who speaks because he has something to say, and speaks and says because he can know, is the real radical reality of what we call language. We have found out a radical reality and we can formulate a theory based on it, including all those aspects examined above and some more we are just going to see.

\section{Mental Relations or Knots of Connections}

All aspects found so far, aspects we must reject if they are considered in themselves with no connection with the speaking subject, do not constitute anything reliable to base a theory on. but they all must be included in the theory we are going to formulate. They all must find explanation based on the radical reality. They all must be explained in terms of the degree of reality they have, that is, in terms of the significance they have in connection with the speaking subject, the real radical reality.

The concept of language is useful because it designates the complex reality we want to study and have just analysed. Anything we have analysed constitutes aspects, that is, connections founded on the reality of the thing we call language. The reality of language consists precisely in designating the set of knots of connections contained in that reality. Language is much more complex than we initially thought. However, language as a concept is not good enough for founding a theory on it. Let us briefly analyse the most important theories about language today.

Chomsky conceives of the reality of language as something there, that is, as something existing in itself. Since it is something there he thinks that it should be studied in human psychology. Because of this he thinks that it is a faculty, the same as with other faculties, that is, something objective. In this way, we cannot understand what language is unless we study it in terms of a theory of learning. Once accepted the theory of learning as the means to study language, he deduced that a theory of learning can only be such a theory, if it reveals innate schemata. Because of this he thinks that language is innate. He then deduced linguistic universals and from this he stated a universal language. Once he had formulated his theory in this way, the only thing to do was establishing the criteria having to do with the theory itself: explanatory adequacy (internal adequacy, that is, adequacy of the theory to itself) and descriptive adequacy (external adequacy, that is, adequacy in terms of the language use of the language being studied) ${ }^{16}$.

\footnotetext{
${ }^{16}$ Cf. a summary of Chomsky's theory in Martínez del Castillo 2012, pp. 75-96; cf. as well Martínez del Castillo 2006.
} 
Starting with these assumptions, Chomsky's theory is nothing but a set of attempts to achieve the full explanation of that thing there, some of his developments, cognitivism, naturalism and bio linguistics, in fragrant contradiction with the principles of his initial theory ${ }^{17}$.

The concept of a particular language is useful as well. It designates the execution of language within a linguistic community. In itself it constitutes idiomatic knowledge $e^{18}$, the reality we have to analyse in order to start with and see how language functions. A particular language in itself does not constitute anything reliable to base a theory on. Ferdinand de Saussure based his theory on the idiomatic knowledge of a particular language. De Saussure's theory ${ }^{19}$ meant the orientation of language to the behaviour of speakers but he did not contemplate language as dynamic, that is, as an activity. Language, for De Saussure, was something objective, ruled by a system liable to change only in its execution, la parôle. For De Saussure, la langue was something already made, something governed systematically under inexorable rules. In De Saussure's conception language could not change: change was something off the system but affecting the system negatively, that is, change was corruption. So he established some irreconcilable dichotomies: synchrony/diachrony, langue/parôle, system/substance.

Speaking, rather than a useful concept, constitutes a set of knots of connections. Speaking is useful as the object to study. This must be considered in terms of the radical reality it is based on, human subjects.

\section{A Theory of Knowledge}

Out of all aspects underlined in the activity of speaking it is worth considering the fact that language is the result of an act of knowing. Because of this, a theory about language must be a theory of knowledge. A theory of knowledge can only be explained if we base it on a cognizant subject. In itself, without any connection with a subject able to know, a theory of knowledge is not enough to study anything human. And this is the failure of both Whorf and Chomsky, each one in a different way. For Chomsky, since he conceived of language as something objective lying on human psychology, a "theory of learning" should be adequate to language study, that is, it should explain how objective things are learnt objectively, because there must be certain innate schemata making learning possible.

Whorf, who formulated language as the way of thinking of (a linguistic "group" of) people, considered language and thought as something unique, something already made, something objective in itself. In this way he omitted the participation of individuals, attributing speakers unconsciousness when speaking ${ }^{20}$. Because of this and

\footnotetext{
${ }^{17}$ Cf. Martínez del Castillo 2012, pp. 97-112.

${ }^{18}$ Cf. Coseriu 1982, p. 313

${ }^{19}$ Cf. Saussure 1974

20 "Which fact most of us are blissfully unaware of" (Whorf 1956, p. 82)
}

contrary to any theory of knowledge, Whorf appealed to reality as something prior to language, that is, reality was structured independent from language ${ }^{21}$.

\section{Linguistics or the Study of Language}

Summing up, in the activity of speaking we have seen that all aspects studied are based on the reality of a subject who speaks and executes what language is at any moment. We have concluded that the speaking subject (level of the individual execution and the level of creation-universal), or the set of subjects constituting a speech community (level of historical execution, thus the level of contingency and historicity), constitute what we were looking for: the radical reality. On the other hand, we have seen that the many concepts involved with speaking constitute the set of aspects we must study. As a consequence, if the speaking subject, that is, the human subject is absolute, that is, a free and creative cognizant subject, and at the same time it is contingent and limited, a historical subject, the discipline studying this double reality in language cannot be any discipline. It must be a primary science, that is, a science giving the foundation to all other disciplines, because it deals with human beings and what constitutes human beings. This science cannot be a positive science, biology, psychology or any other. These disciplines study partial aspects of human beings, especially today when language, since the late $20^{\text {th }}$ century tends to be studied in psychology, based on the structural nature of human beings. Speakers do not speak because they have internal impulses to speak but just the contrary: speakers speak because, not having any impulses to do anything, they must survive in the circumstance they are in at any moment with the only means of their intuition and freedom. Linguistics must be a fundamental discipline because it deals with the subjects creating reality, the linguistic world they live in, and the means used by those subjects to create reality and the world. At the same time the object created by that subject evinces that the subject having created reality and the world must be free and intelligent. Language evinces the creativity, freedom, intelligence and contingency of those creative subjects. The object of study of linguistics is thus the human being in so far as he speaks and says, and because he speaks and says, he knows. Linguistics is basically a theory of knowledge, that is, linguistics is philosophy.

Trying to make philosophy out of "the three major findings" of cognitive sciences ${ }^{22}$ has no sense. It is just the contrary: because cognitivists have "discovered" that knowledge exists, calling it, cognition, thus focussing their contribution on beliefs, something they found in cognition as something natural, they conceive of the world differently. The philosophy they look for is the one they have previously accepted, the one making them reflect on what people conceive of. Accepting a

\footnotetext{
${ }^{21}$ Cf. Whorf 1956, p. 139.

22 "[...] the mind is inherently embodied, thought is mostly unconscious and abstract concepts are largely metaphorical” (cf. Lakoff \& Johnson,. p. 3.).
} 
theory of knowledge and trying to find out beliefs on human psychology is a dogmatic contradiction. Defending linguistics as part of psychology is just reducing linguistics to nearly nothing, because psychology has to do with human beings merely in some aspects, not in their complexity or their reality, that is, merely in certain behavioural tendencies prompted, conditioned or founded in the human psyche. Psychology today focuses human only on the structural nature of human beings (experimental psychology), thus rejecting anything having to do with what makes human beings human ${ }^{23}$.

Leonard Bloomfield, who posed the problem of language as the result of behavioural reactions, excluded meaning from language study, simply because meaning did not have anything to do in his behaviourist theory ${ }^{24}$. A human being is something beyond human psyche and human biology.

\section{Conclusion}

Language cannot be studied unless in human beings, that is, human subjects who speak, say and know. In this sense the radical reality of language and language study is human subjects who individually, on the one hand, and collectively through abstraction, on the other, participate with one another in fight against the circumstance they are in at any moment.

\section{References}

[1] Chomsky, Noam, New Horizons in the Study of Language and Mind, Oxford University Press, 2000.

[2] Chomsky, Noam, On Nature and Language, Oxford University Press, 2002.

[3] Coseriu, E., Principios de semántica estructural, Madrid: Gredos, 1981 (1977).

[4] Coseriu, E., Teoría del lenguaje y lingüística general: cinco estudios, Madrid, Editorial Gredos, 1982 (1962).

[5] Coseriu, E., El hombre y su lenguaje. Madrid: Gredos, 1985 (1977).

[6] Coseriu, E., Introducción a la lingüística, Madrid: Gredos, 1986a.

[7] Coseriu, E., 1986b, Lecciones de lingüística general. Madrid: Gredos.

[8] Coseriu, E., Gramática, semántica, universales. Estudios de gramática funcional, Madrid: Gredos, 1987 (1978).

[9] Coseriu, E., Competencia lingüística: elementos de la teoría del hablar, Madrid: Gredos, 1992 (1988).

[10] Coseriu, E. y Ó. Loureda: Lenguaje y discurso, Pamplona, Eunsa, 2006.

[11] Coseriu, E., Lingüística del texto. Introducción a la hermenéutica del sentido, Arco/Libros, 2007 (1973).

\footnotetext{
${ }^{23}$ Cf. Martínez del Castillo 2008, pp. 233-235.

${ }^{24}$ Cf. Martínez del Castillo 2012, pp. 42-46.
}

[12] Di Cesare, D., Wilhelm von Humboldt y el estudio filosófico de las lenguas, traducción de Ana Agud, Anthropos, 1999.

[13] Heidegger, Martin, El ser y el tiempo, RBA Editores, 2002 (1944).

[14] Humboldt, W., «Ueber die Verschiedenheit des menschlichen Sprachbaues und ihren Einfluss auf die geistige Entwickelung des Menschengesschlechts» trad. Ana Agud: Sobre la diversidad de la estructura del lenguaje humano y su influencia sobre el desarrollo espiritual de la humanidad, Madrid, Anthropos y Ministerio de Educación y Ciencia, (1990) [1836].

[15] Kant, Immanuel, Crítica de la razón pura, RBA Coleccionables, 2004.

[16] Lakoff, George \& Mark Johnson, Philosophy in the Flesh: The Embodied Mind and its Challenge to Western Thought. Basic Books

[17] Martínez del Castillo, Jesús, La intelección, el significado, los adjetivos, Universidad de Almería, 1999.

[18] Martínez del Castillo, Jesús, La lingüística del decir. El logos semántico y el logos apofántico, Granada: Granada Lingvistica,

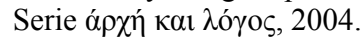

[19] Martínez del Castillo, Jesús, Los fundamentos de la teoría de Chomsky. Revisión crítica. Madrid: Biblioteca Nueva, 2008.

[20] Martínez del Castillo, Jesús, La lingüística cognitiva. Análsis y revisión, Madrid: Biblioteca Nueva, 2008.

[21] Martínez del Castillo, Jesús, «Hablar, decir y conocer: el acto lingüístico», Oralia, 11 (2008b): 375-97.

[22] Martínez del Castillo, Jesús: «El logos semántico y el logos apofántico» Enérgeia I, Online-Zeitschrift für Sprachwissenchaft, Sprachphilosophie und Sprachwissenschaftsgeschichte (2009): 50-80.

[23] Martínez del Castillo, Jesús: Las relaciones lenguaje-pensamiento o el problema del logos. Madrid: Bilbioteca Nueva, 2010.

[24] Martínez del Castillo, Jesús, Sobre las categorias, Buenos Aires: Deauno.com, 2011.

[25] Martínez del Castillo, Jesús, ed. Eugenio Coseriu (1921-2002) en los comienzos del siglo XXI, 2 vols. in Analecta Malacitana, Anejos/86, 2012.

[26] Martínez del Castillo, Jesús: Psicología, lenguaje y libertad, in Analecta Malacitana, Anejos/89, Universidad de Málaga, 2012.

[27] Martínez del Castillo, Jesús: Modes of Thinking, Language and Linguistics, in Analecta Malacitana, Anejos/94, 2013, Universidad de Málaga.

[28] Ortega y Gasset, José, Goethe, Dilthey, Alianza Editorial, 1982 (1958).

[29] Ortega y Gasset, José, El tema de nuestro tiempo, Alianza Editorial, 1987 (1981).

[30] Ortega y Gasset, José, Origen y epílogo de la filosofía, Alianza Editorial, 1989 (1981).

[31] Ortega y Gasset, José, La idea de principio en Leibniz, Alianza Editorial, 1992a (1958).

[32] Ortega y Gasset, José, ¿Qué es conocimiento?, Alianza Editorial, 1992b (1984). 
[33] Ortega y Gasset, José, ¿Qué es filosofia?, Alianza Editorial, 1994 (1957).

[34] Ortega y Gasset, José, Sobre la razón histórica, Alianza Editorial, 1996 (1979).

[35] Ortega y Gasset, José, «El decir de la gente: la lengua. Hacia una nueva lingüística» in El hombre y la gente, Alianza Editorial, 2001 (1957).

[36] Ortega y Gasset, José, Unas lecciones de metafísica, Alianza Editorial, 1999 (1966).

[37] Ortega y Gasset, José, «El decir de la gente: las 'opiniones públicas', las 'vigencias sociales"”. El poder público» in El hombre y la gente, Alianza Editorial, 2001 (1957).

[38] Ortega y Gasset, José, "En torno al coloquio de Darmstadt", in Meditación de la técnica y otros ensayos de ciencia y filosofía, 2002 (1982): 192-233.

[39] Ortega y Gasset, José, En toro a Galileo, Madrid, Biblioteca Nueva, 2005 (1933).
[40] Ortega y Gasset, José, "Apuntes para un comentario al banquete de Platón“, Obras completas, IX, Taurus, 2009: 729-758.

[41] Popper, Karl, The Logic of Scientific Discovery, London \& New York, Routledge Classics, 2002 (1959).

[42] Saussure, Ferdinand de, Course de lingüístique générale, published by Charles Bally and Albert Sechehaye, Paris, 1916, Spanish tr., Curso de lingüística general, Amado Alonso, tr., Buenos Aires: Editorial Losada, S. A., 1974 (1945).

[43] Whorf, Benjamin Lee, Language, Thought and Reality: Selected Writings of Benjamin Lee Whorf. John B. Carroll, ed., Cambridge, Massachussets: The MIT Press, 1956. 